\title{
Sexuální výchova ve školách meziválečného Československa
}

\section{Magdaléna ŠustovÁ}

\author{
ARTICLE INFO \\ Article history: \\ Received 3 November 2019 \\ Accepted 20 December \\ 2019 \\ Available online 31 \\ December 2019

\begin{tabular}{|c|}
\hline $\begin{array}{l}\text { Keywords: } \\
\text { sex education, coeducation }\end{array}$ \\
\hline $\begin{array}{l}\text { M. Šustová } \\
\text { Muzeum hlavního města } \\
\text { Prahy • } \\
\text { Na Poŕíćí 52/1554 } \\
18000 \text { Praha } \bullet \\
\text { Česká republika } • \\
\text { theatralia@ muzeumprahy. }\end{array}$ \\
\hline
\end{tabular}

\begin{abstract}
The Sex Education in Schools of Interwar Czechoslovakia

The problematics of sex education got into the focus of pedagogues in the end of the $19^{\text {th }}$ century and a new insight was brought up by the interwar period. The social and moral disintergration, caused by World War I, came up with a necessity of an enlightenment in sex education due to prostitution and increase of veneral diseases - the enlightenment regarding the sex education was emphasized in order to prevent sexually transmitted diseases. The position of the school authority was in this case difficult, because part of the society thought that the sex education was only a private family topic or that it was not necessary at all. Therefore, the school usually warned against veneral diseases by lectures, intervened against pornographic materials etc., and to some topics (contraception, abortion) it did not pay attention at all.
\end{abstract}

Uvedení sexuální výchovy do škol není - jak by se mohlo zdát - výdobytkem druhé poloviny 20., či dokonce počátku 21. století. Jak v posledních dvou desetiletích sílí historické bádání v tajemstvích ženského světa, zvyšuje se i úroveň poznání intimního soužití předků a s ním úzce související problematiky prostituce, antikoncepce i sexuální výchovy. V posledních letech byla často věnována pozornost proměně postavení žen ve společnosti, se kterým souvisí i otázky sexuality a sexuální výchovy (především Žena v českých zemích od středověku do 20. století, 2009 a Tělo mezi medicínou a disciplínou, 2014, zde i další literatura), a to nejen v rodinném, ale i školním prostředí. Otázka sexuální osvěty ve školním prostředí v první polovině 20. století je v souvislosti se společenskými změnami, které přinesla 1. světová válka, a se snahami o proměnu československého školství, fenoménem, kterému bychom měli věnovat pozornost. Cílem této stati je tak především popsat snahy o započetí cílené sexuální výchovy mládeže a diskusi, zda se má tato osvěta odehrávat ve škole, či v rodině. Díky dobovým příručkám je možné rekonstruovat ideální obsah sexuální výchovy i její začlenění do výchovy mládeže, kvůli omezeným pramenným zdrojům však nemůžeme činit nárok na hlubší analýzu skutečné úrovně sexuální výchovy meziválečné mládeže.

Otázkou sexuální osvěty u mládeže i jejím sexuálním životem se ve spisu Emil zabýval již Rousseau, po něm se na toto téma zaměřili i další autoři, $\mathrm{z}$ nichž v českém prostředí byl patrně nejrozšířenější Pařízkův překlad Willaumovy Praktické knihy ruční z roku 1790. V polovině 
19. století pak na tyto snahy navázal Stanislav Kodym svou Zdravovědou. ${ }^{1}$ Pro 19 . století bylo zejména pro středostavovské rodiny charakteristické v každodenním životě oddělovat dospívající chlapce a děvčata, $v$ nižších sociálních vrstvách sice nebyli dospívající tolik separováni, avšak i se zde sexuální výchova sestávala často z velmi obhroublé osvěty provedené staršími kamarády či sourozenci. Velmi často tak byla děvčata v oblasti sexuálního života poučena velmi nedostatečně a o toto drastičtější mohly být zážitky ze svatební noci (Lenderová, Kopičková, Burešová a Maur, 2009, s. 231); chlapcům se skýtaly zcela odlišné možnosti, které stejně chatrné vědomosti v oblasti intimního soužití ještě před sňatkem mohly rozhojnit. Řada středo- i vysokoškolských studentů byla uvedena do sexuálního života $\mathrm{v}$ raném věku, a to dosti riskantní formou. Historik a mj. i jeden z meziválečných ministrů školství Josef Šusta byl do „veřejného domu zcela lůzovitého prídechu“ v Českých Budějovicích zaveden spolužákem $\mathrm{v}$ den svých 14. narozenin a tato návštěva jej natolik šokovala, že nejenom téměř okamžitě prchl, zanechávaje na místě klobouk, ale ,jako gymnasista již nikdy o prostředí prodejné lásky nezavadil, ač se z mých spolužáki̊ někteří, vyspělejši svými zkušenostmi, na těchto smutných pěšinkách mnoho vychloubalo“ (1947, s. 147). Pokud se prostředí prodejné lásky zdálo př́liš riskantní, navazovali dospívající mladíci vztahy se staršími dívkami a ženami ze svého okolí (často se jednalo o služebné či děvečky). V roce 1908 publikoval lékař pražské dermatovenerologické kliniky Hugo Hecht spisek o pohlavních chorobách středoškolské mládeže (1908). Ze vzorku 3709 abiturientů, kteří byli téměř rovnocenně rozprostřeni na pražských a venkovských středních školách, trpělo 7,9 \% pohlavní nemocí. Pražští studenti měli méně infikovaných $(7,7$ \%) než venkovští středoškoláci (8,1 \%) (citováno dle Štech, 1920, s. 21). Lékař Antonín Trýb k této statistice dodává (bohužel bez uvedení zdroje), že v rakousko-uherské armádě trpělo asi $5 \%$ vojáků venerickou chorobou (Trýb, 1931, s. 35). Tyto smutné údaje vedly roku 1917 spolkovou radu Pedagogického musea v Praze k podání „O pohlavní výchově mládeže“ c. k. české zemské radě, v němž navrhovala, aby se sexuální výchova stala součástí školního vzdělávání; aby byly uspořádány školicí kurzy pro učitele i osvětové přednášky pro veřejnost a aby byla vyvolána veřejná diskuse o účelných opatřeních. Pisatelé tohoto návrhu zmiňují, že jejich motivací bylo především značné rozšiřřní venerických chorob v době první světové války.

Po první světové válce se však o sexuální osvětě rozviřuje rozsáhlá veřejná diskuse, která byla zapříčiněna především těžkými válečnými léty, když pro řadu žen a jejich rodin bylo tzv. nejstarší řemeslo zdrojem obživy. V roce 1922 byl vydán zákon č. 241/1922 Sb. ze dne 11. července 1922, O potírání pohlavních nemocí, který zapovídal provozování nevěstinců, prostituce však nezmizela, byla pouze vytlačena do barů, vináren a temných zákoutí. Řadu problémů totiž generovalo rodinné zázemí dětí, které na prostituci (a potenciální styk chlapců s prostitutkami) nahlíželo jako na něco téměř normálního. Zkušenost, kterou zaznamenal Antonín Trýb ve své příručce o sexuální výchově, se nám dnes zdá těžko uvěřitelnou: „Znám

\footnotetext{
${ }^{1}$ KODYM, Filip S., 1853. Zdravověda, čili Nejlepši způsob, jak by člověk svého života ve zdraví a vesele užití a dlouhého věku dosáhnouti mohl. Praha.
} 
př́pad, kdy hoch obecné školy uzmul doma penize, pozval dva spolužáky, najal pokoj v hotelu a prostitutku, aby zaučoval kamarády. Když věc propukla a učitel zakročil, prohlásila matka dotyčného hocha, že po tom, co dělá její chlapec mimo školu, učiteli nic není. A zmíněný hoch zůstal ve škole dále, poněvadž inspektor, patrně po neblahých jiných zkušenostech, prohlásil, že je nejlépe věc ponechati tak." (Trýb, 1931, s. 37).

Jednou z prvních snah, kterou v otázce zavádění sexuální výchovy zaznamenáváme ve školském prostředí, je několik otázek kladených v rozsáhlé anketě o reformě střední školy (Výsledky ankety ministerstva školství a národní osvěty z roku 1919 o reformě střední školy, 1922). Byly součástí bloků otázek o tzv. zdravovědě, kam byla řazena nejenom tzv. pohlavní výchova, ale obecně zásady správné životosprávy; o mravní výchově a školních lékařích (Tamtéž, 1922, s. 43-44, 97-99, 118-119). Zde 89,9\% odpovědí pokládalo zdravovědné vzdělání za nedostatečné, a proto bylo navrhováno, aby žáci byli poučováni nejenom v prrírodopisu či tělocviku, ale také specializovanými prrednáškami školních lékařù, a část odpovědí dokonce požadovala zařazení této problematiky do všech předmětů - tedy učinit z ní v dnešní terminologii tzv. průřezové téma. Objevil se dokonce názor učinit ze zdravovědy samostatný vyučovací předmět. Účastníci ankety zodpovídali i otázku, kdo by měl tyto přednášky zajišt'ovat - 68,2 \% odpovědí mělo za to, aby tak činil profesor (především př́rodopisci) v prŕípadné spolupráci se školním lékařem. Odpovídající však neviděli řešení pouze ve zdravovědném vzdělávání mládeže, ale také v posílení etické výchovy, a to nejenom volbou vhodné literatury do žákovských knihoven a bojem s pornografií, ale také podporou žákovské samosprávy, podporou umělecké výchovy vč. pořádání koncertů a divadelních představení. V anketě se setkáváme také s dalším velkým tématem prvorepublikového školství, které s otázkou sexuální výchovy poměrně úzce souviselo, a to s koedukací. Společné vyučování chlapců a dívek v obecných školách bylo běžné od tereziánských reforem školství, avšak ve větších obcích byly zřizovány oddělené chlapecké a dívčí školy. Na středních školách bylo sice možné využít tzv. hospitace studentek ve tř́iě, avšak pravidla byla nastavena tak, že dívky byly v podstatě přítomny pouze výuce, jíž se nijak aktivně neúčastnily, a o přestávce byly vyučujícím odvedeny na vyhrazené místo, kam studující chlapci nesměli. Ve výše uvedené anketě se z 363 odpovědí vyslovilo 45 respondentů zásadně proti koedukaci, 58 zásadně pro edukaci, 11 pro edukaci na nižším stupni střední školy (tj. v primě až kvartě) a 249 bylo pro koedukaci podmínečně, a to proto, aby dívky mohly studovat i tam, kde není možné zřídit samostatnou státní dívčí stř̌ední školu (Tamtéž, 1922, s. 26-27). Meziválečná republika tento problém vyřešila docela šalamounsky - v menších obcích dále fungovaly koedukované školy (především obecné), ve větších městech byly nadále zřizovány oddělené školy; střední školství pak dosáhlo značné koedukace, a to především z ekonomických důvodů - kromě velkých měst nebylo finančně únosné vydržovat školy gymnaziálního typu.

Známe-li díky výše uvedené anketě alespoň částečný názor odborné veřejnosti, logicky si položíme otázku, jak reagovala na tyto snahy laická veřejnost? Její názory nám do jisté míry 
odhalují meziválečné př́ručky sexuální výchovy. Veřejnost se tak jako dnes dělila na zastánce a odpůrce sexuální výchovy, přičemž „odmítači“ používali jako nejčastější argument, že se o tomto tématu nemá vůbec hovořit či že není potřeba o něm hovořit (zvířata též nepotřebují „školení“). Vyvstával zde samozřejmě i problém, že pokud by sexuální výchova byla nařízena jako povinná součást školního vzdělávání, došlo by ke vstupu státu do této velmi citlivé oblasti dosud vyhrazené rodině. Zastánci z řad lékařů a pedagogů však tuto roli státu připouštěli především proto, že řada děvčat se $\mathrm{k}$ prostituci dostala právě pod vlivem rodiny, či morální úroveň rodin byla dosti nevalná (pro úplnost dodejme, že př́ručky sexuální výchovy prostituci chlapců vůbec nezmiňují; hoši byli v podstatě morálními obět'mi ženské prostituce). Není bez zajímavosti, že školní řád pro střední školy vydaný roku 1936 umožňoval škole dohlížet na ubytování přsespolních studentů, a v př́ípadě, že domácnost, v níž bydleli, byla shledána mravnostně nevyhovující, bylo možné žádat rodiče dotčených studenti̊, aby je přestěhovali.

V příručkách sexuální výchovy bylo také intenzivně řešeno, kdy s osvětou začít a kdo by se jí měl zhostit. Obecně se doporučovalo s ní začít co nejdř́ve a v rozsahu samozřejmě úměrnému věku dítěte. Základy měly být položeny ve chvíli, kdy se dítě zeptalo, jak se dostalo na svět. „Bajkám o čápu a vráně nevěri dnes už nikdo, a napovídáme-li to dětem, pak ony za krátko někde se doví, že si z nich matka udělala blázna. To musí přestati.“ (Trýb, 1931, s. 23). Autoři příruček o sexuální výchově obecně doporučovali, aby dítě poučila osoba, se kterou má blízké vztahy, tedy ideálně rodič. Proti činnosti pedagogů v této oblasti hovořilo několik argumentů: jednak to byla značná naplněnost tříd - v meziválečném Československu se v jedné tř́ídě obecné či měšt’anské školy mohlo sejít mezi 50-80 žáky; i v tzv. pokusných školách, které měly na tehdejší poměry menší počet žáků ve třídě, jich běžně bylo mezi 30-40. Druhým úskalím, se kterým se př́ípadná školní osvěta musela vyrovnat, byl zejména mezi starší generací pedagogů často autoritativní přístup $\mathrm{k}$ žákům a $\mathrm{z}$ toho vyplývající ostych až hrůza položit učiteli doplňující otázku. Třetím problémem, na který bylo často poukazováno, byl fakt, že sexuální výchovu není možné „odbýt“ několika vyučovacími hodinami, ale že je to téma, kterému by měla být věnována dlouhodobá pozornost. Tím se ideálním poučujícím stává opět rodič či jiná blízká důvěryhodná osoba.

Pokud jsme se pokusili odpovědět si na otázku, kdo měl děti poučit, vyvstane logicky i otázka, jaká témata měla být $\mathrm{v}$ rámci sexuální výchovy otevřena. Kromě seznámení s biologickou stránkou pohlavního styku a těhotenství, stejně jako s existencí venerologických chorob, kladli autoři meziválečných příruček sexuální výchovy největší důraz na fakt, že sex je součástí citového života člověka. Dnes se nám může zdát akcent, který byl na tento směr kladen, až přehnaný, ale musíme si uvědomit, že zejména městské děti z nižších sociálních vrstev žily často v morálním prostředí, jehož úroveň (či spíše dno) si dnes sotva umíme představit. Obecně lze shrnout, že předmanželský pohlavní styk, a to nejenom v komerčním prostředí prodejné lásky, byl považován za stále nevhodný (u chlapců) až nepřípustný (u dívek). V podstatě zcela chybí poučení o antikoncepčních metodách, a to pravděpodobně 
z několika následujících důvodů. Vynecháme-li názor církevních autorit, i řada intelektuálů (v českém prostředí i T. G. Masaryk) chápala jako jedinou přijatelnou antikoncepční metodu (a to i v manželství) zdrženlivost. Můžeme se setkat i s propagací větších rodin (3-4 děti), aby byl vyrovnán populační propad způsobený první světovou válkou (Štech, 1920, s. 7). A dalším důvodem byla pravděpodobně i skutečnost, že použití kondomu bylo chápáno jako morálně škodlivé, a to nikoli pro odporování církevním dogmatům, ale proto, že v tehdejších očích podporovalo nevázané vztahy a nemorálnost. Diskusi o antikoncepčních metodách, ale také legalizaci potratů rozviŕila především ve 30. letech 20. století senátorka Betty Karpíšková, pro školní prostředí však byly tyto názory prŕliš kontroverzní a vůbec se v něm neobjevují.

Dalším tématem, které autoři příruček sexuální výchovy hojně řešili, bylo masturbování. Popisovali jej jak u chlapců, tak u děvčat a kořeny hledali jak v hormonálních změnách provázejících dospívání, tak i v nošení některých oděvních prvků (kombiné, podvazky, těsné prádlo apod.). Samostatně řešeným problémem je pak masturbování mentálně postižených dětí. Právě u tohoto tématu je kladen velký důraz na výchovu v rodině, protože autoři příruček doporučovali nošení vhodného prádla, úpravu jídelníčku či sportovní aktivity, což jsou oblasti, do kterých pedagogové téměř nemohli zasáhnout. V doporučeních se také objevují rady, aby dospívající nebyli zbytečně děšeni následky masturbování - starší literatura často tvrdila, že způsobuje tuberkulózu, měknutí mozku, padoucnici apod. (Skořepa, 1932, s. 29; Trýb, 1931, s. 26). Přŕručky sexuální výchovy velmi zřídka zmiňují problematiku homosexuality (Skořepa, 1932, s. 31), která byla v meziválečném Československu trestná, tudíž se logicky neobjevuje mezi doporučenými tématy sexuální výchovy.

Díky př́ručkám sexuální výchovy i periodickému tisku máme docela dobrou představu, jak měla osvěta $\mathrm{v}$ ideálním př́ípadě probíhat, avšak hưře si odpovíme na otázku, jak reálně vypadala. Malý vhled nám umožňuje spis Jana Uhra Středoškolský student a jeho svět z roku 1939. Autor v letech 1931-1937 provedl v Brně na mužském a ženském učitelském ústavu a na pedagogické akademii dotazníkové šetření mezi 330 studenty (164 studentů a 166 studentek) a sérii otázek věnoval i úrovni sexuální výchovy respondentů. Nebylo povinné opovědět na všechny otázky, proto vzorek odpovědí je poměrně malý a kolísavý, pro nás je však velmi zajímavý. O zdroji poučení se vyjádřilo 166 studujících (77 chlapců, 89 dívek), z nichž 71 bylo informováno spolužáky, a většina odpovědí jej popisuje ,jako nevážné, hrubé, sprosté, nedostatečné, špinavé, nebo alespoň kluzké. Jeden za mnohé píše, že vlivem takového poučení pochopil pohlavnost jako nejnestydatější věc." (Uher, 1939, s. 56). Dalších 26 respondentů poučila matka, 2 otec, 4 některý z rodičů, 6 sourozenci, 3 jiní příbuzní, 24 škola, 18 literatura, 2 jiné osoby a 10 účastníků zůstalo nepoučeno (Tamtéž, s. 55). Pokud se na tomto vzorku zaměříme na osvětu v rodině, dojdeme $\mathrm{k}$ alarmujícímu zjištění - z 89 dívek bylo 31 poučeno nějakým rodinným př́slušníkem, ze 77 chlapců pak rodina vzdělala pouhých 10! Jestliže tedy pouhých 41 rodin ze 166 podniklo kroky v oblasti sexuální osvěty, byly snahy o zavedení této problematiky do školní výuky zcela legitimní. Vidíme ovšem, že ani 
škola, která byla zdrojem informací pro 24 respondentů, nefigurovala jako nejpilnější osvětový pracovník. Zajímavý je i výsledek odpovědí na otázku pátrající po pramenech dalšího poučení (Tamtéž, s. 57-59), kterým byly různé populárně-naučné spisy, o nichž se autor vyjádřil, že „Z některých těchto knih jsme se poučovali už i my. Od našich dob se na nich změnilo snad jen vydání.“ (Tamtéž, s. 59). Proto důrazně doporučoval vydávání nových príruček určených mládeži.

Velmi zajímavé jsou i odpovědi na otázku, jak respondenti na poučení reagovali, které Jan Uher velmi pečlivě analyzoval (Tamtéž, s. 60-92). Opovědělo 128 studujících (58 chlapců, 70 dívek) a jasně se ukázalo, že dospívající, kterým se dostalo dobrého či alespoň nepř́liš vulgárního poučení (68 \% chlapců a 43 \% dívek), si neprošli různými psychickými zmatky a traumaty, které jejich méně št’astným vrstevníkům nově nabyté vědomosti přinesly. Sám autor tuto část své analýzy shrnuje: „Pohlavní výchova naši mládeže musí být postavena na nové základy. Ukázalo-li se nám žretelně na sebraných faktech, že velká část mládeže jest bez dobrého poučení, ba naopak že poučení, kterého se jí dostává, jí zpưsobuje škody, a to nezř́lka škody trvalé, že při zápasech a poblouzeních se jí nepodává ruka a nedostává se jí pomoci v té míre, jak by bylo třeba, že vlastně není pohlavní výchovy, musíme pochopit (rodiče i učitelé), že je hřich nepřispět na pomoc tam, kde se žrejmě prokáže, že pomoci je třeba." (Uher, 1939, s. 93-94).

Uher neopominul do svého výzkumu zařadit i otázku koedukace, kterou bezvýhradně přijímalo 135 respondentů z 330 (76 dívek, 59 chlapců), zcela ji odmítalo 57. Studenti měli s koedukací zkušenosti od zcela minimálních, které se omezovaly na 1. třídu obecné školy, až po maximální. Co ovšem chlapci na koedukaci oceňovali, byl fakt, že pro ně představovala možnost se přirozeně setkávat se svými vrstevnicemi, jelikož někteří se v rodině nesetkali se společenskou výchovou a na prahu dospělosti v podstatě netušili, jak se k dívkám chovat.

Pokud shrneme školní sexuální výchovu mládeže v meziválečném Československu, musíme konstatovat, že přes značnou snahu pedagogů i lékař̊̊, kterou vyvíjeli již v průběhu 19. století, se dospívajícím př́lišného poučení nedostalo. Vrátíme-li se k výsledkům Uhrova výzkumu, zjišt'ujeme, že se školní osvětou v oblasti sexuální výchovy se setkalo poměrně malé procento studentů, na druhou stranu to byla dle jejich slov osvěta kvalitní. Jak ovšem dobové příručky podotýkaly, jádro řady problémů tkvělo v nevalné výši morálního života rodičů i v rozvratu zaviněného 1 . světovou válkou. Jelikož neexistoval učební předmět, který by se věnoval širšímu tématu zdravovědy a zdravého způsobu života, role školy se tak často omezila na př́slušné kapitoly v biologii, na přednášku/y o pohlavních chorobách a případný boj s pornografickými materiály. Normativní literatura sice zdůrazňovala, že sexuální život je součástí života citového, zůstává však otázkou, jak se škole, resp. pedagogům, dařilo tento úkol plnit. Připomeneme-li si aktivity některých pedagogů působících v meziválečné Praze (např. Anna Hlavatá-Pokorná či Přemysl Pitter), kteří se věnovali sociální činnosti ve čtvrtích, kde žily nižší sociální vrstvy (Holešovice, Žižkov), je nám jasné, že aktivity školy, jakkoli by byly rozsáhlé, nemohly postačovat. Prostituce, sexuální zneužívání, alkoholismus a bída zde 
byly nedílnou součástí každodenního života. Řešení situace spočívalo v trpělivé sociální práci a ani ta nebyla vždy úspěšná. O některých otázkách, které souvisely s emancipací žen (antikoncepce, interrupce), vedli diskusi především představitelé politického života a škola je zcela opomíjela. Musíme však přiznat, že přes veškerou opatrnost, která provázela veřejnou diskusi o nutnosti sexuální výchovy v rodině i ve škole, se školy - v krátkém čase vyměřeném meziválečné republice - s tímto novým tématem naučily přiměřeně pracovat, i když reálný dopad těchto snah byl omezený kvůli velkému vlivu rodinného prostředí.

\section{Seznam použitých pramenů a literatury}

EXNER, Max J., 1925. Pohlavní život pred sňatkem pro mladé muže. Praha: B. Kočí.

HECHT, Hugo, 1908. Verbreitung der Geschlechtskrankheiten an den Mittelschulen. Leipzig. O pohlavní výchově mládeže. Podání spolkové rady Pedagogického musea Komenského C. $k$. zemské školní radě pro Král. české, 1917. Praha: Spolková rada pedagogického musea Komenského.

KRAUS, Franišek, 1906. Přehled požadavků školního zdravotnictví. Velké Meziříčí: Alois Šašek s. d.

MEJSNAR, Karel, 1931. Středoškoláci diskutují. Př́ručka pro praktické vedeni diskusních kroužků středoškolských. Praha: YMCA.

Odpovědi k naší 3. soutěži, 1924-25. In: Sbratření. Roč. I, příloha Studánka, s. 3-4.

PITTER, Přemysl, 1939. Moc a nemoc mládí. In: Sbratření. Roč. XV. (1939), č. 2, s. 4-5.

SKOŘEPA, Miloslav, 1932. Pohlavní výchova naši mládeže. Praha: Státní nakladatelství.

SVOBODA, Emil, 1925. Žena-člověk. Praha: B. Kočí.

ŠTĚCH, Karel, 1920. O pohlavní výchově. Praha: Gustav Voleský.

ŠUSTA, Josef, 1947. Léta dětství a jinošství. Vzpomínky I. Praha: Melantrich.

ŠUSTOVÁ, Magdaléna, 2018. Vychovatel, či policajt? Studenti a meziválečné střední školy v Československu. In: Dějiny a současnost. Roč. XL (2018), č. 3/2018, s. 37-39.

LENDEROVÁ, Milena, TINKOVÁ, Daniela a HANULÍK, Vladan, eds., 2014. Tělo mezi medicínou a disciplínou. Proměny lékařského obrazu a ideálu lidského těla a tělesnosti $v$ dlouhém 19. století. Praha: Nakladatelství Lidové noviny.

TRÝB, Antonín, 1931. O sexuální výchově. Praha: Státní nakladatelství.

UHER, Jan, 1939. Středoškolský student a jeho svět. Praha: Profesorské nakladatelství a knihkupectví.

Výsledky ankety ministerstva školství a národni osvěty z roku 1919 o reformě středni školy, 1922. Praha: Státní nakladatelství.

ZÁHǑ̌, Zdeněk, 1925. Význam a podstata lásky pro mladé lidi. Praha: B. Kočí.

LENDEROVÁ, Milena, KOPIČKOVÁ, Božena, BUREŠOVÁ, Jana a MAUR, Eduard, eds., 2009. Žena včeských zemích od středověku do 20. století. Praha: Nakladatelství Lidové noviny. 